Correspondence

Denis H. Lynn

ddr@uoguelph.ca

\section{Barcoding ciliates: a comprehensive study of 75 isolates of the genus Tetrahymena}

\author{
Chitchai Chantangsi, ${ }^{1} \dagger$ Denis H. Lynn, ${ }^{1}$ Maria T. Brandl, ${ }^{2}$ Jeffrey C. Cole, ${ }^{3}$ \\ Neil Hetrick ${ }^{3}$ and Pranvera Ikonomi ${ }^{4}$
${ }^{1}$ Department of Integrative Biology, University of Guelph, Guelph, Ontario N1G 2W1, Canada
${ }^{2}$ United States Department of Agriculture, Agriculture Research Service, Western Regional
Research Center, Food Safety and Health Unit, 800 Buchanan St, Albany, CA 94710, USA
${ }^{3}$ Protistology Department, American Type Culture Collection, 10801 University Blvd, Manassas, VA 20110-2209, USA
${ }^{4}$ Molecular Authentication Resource Center, American Type Culture Collection, 10801 University Blvd, Manassas, VA 20110-2209, USA

\begin{abstract}
The mitochondrial cytochrome-c oxidase subunit 1 (cox1) gene has been proposed as a DNA barcode to identify animal species. To test the applicability of the cox 1 gene in identifying ciliates, 75 isolates of the genus Tetrahymena and three non-Tetrahymena ciliates that are close relatives of Tetrahymena, Colpidium campylum, Colpidium colpoda and Glaucoma chattoni, were selected. All tetrahymenines of unproblematic species could be identified to the species level using $689 \mathrm{bp}$ of the cox1 sequence, with about $11 \%$ interspecific sequence divergence. Intraspecific isolates of Tetrahymena borealis, Tetrahymena Iwoffi, Tetrahymena patula and Tetrahymena thermophila could be identified by their cox 1 sequences, showing $<0.65 \%$ intraspecific sequence divergence. In addition, isolates of these species were clustered together on a cox1 neighbour-joining (NJ) tree. However, strains identified as Tetrahymena pyriformis and Tetrahymena tropicalis showed high intraspecific sequence divergence values of 5.01 and $9.07 \%$, respectively, and did not cluster together on a cox $1 \mathrm{NJ}$ tree. This may indicate the presence of cryptic species. The mean interspecific sequence divergence of Tetrahymena was about 11 times greater than the mean intraspecific sequence divergence, and this increased to 58 times when all isolates of species with high intraspecific sequence divergence were excluded. This result is similar to DNA barcoding studies on animals, indicating that congeneric sequence divergences are an order of magnitude greater than conspecific sequence divergences. Our analysis also demonstrated low sequence divergences of $<1.0 \%$ between some isolates of $T$. pyriformis and Tetrahymena setosa on the one hand and some isolates of Tetrahymena furgasoni and T. Iwoffi on the other, suggesting that the latter species in each pair is a junior synonym of the former. Overall, our study demonstrates the feasibility of using the mitochondrial cox 1 gene as a taxonomic marker for 'barcoding' and identifying Tetrahymena species and some other ciliated protists.
\end{abstract}

†Present address: Department of Zoology, University of British Columbia, Biological Sciences Bldg, 6270 University Blvd, Vancouver, British Columbia V6T 1Z4, Canada.

Abbreviations: CVP, contractile vacuole pore; K2P, Kimura two-parameter; LSU, large subunit; NJ, neighbour-joining; PBG, polar basal granule; SSU, small subunit.

The GenBank/EMBL/DDBJ accession numbers for the cox1 and SSU rDNA sequences determined in this study are EF070242-EF070328, as detailed in Supplementary Table S1.

Details of the strains examined in this study, including sequence accession numbers, details of the nucleotide compositions of the cox1 and SSU rDNA sequences, values of overall, within-genus and between-genera divergence of datasets of the cox 1 sequences and alignments of cox 1 and SSU rDNA sequences are available as supplementary material with the online version of this paper. 


\section{INTRODUCTION}

DNA-based identification has been proposed to serve as an alternative taxonomic approach for identifying the immense diversity of living organisms (Dawkins, 1998; Tautz et al., 2002, 2003). Hebert et al. (2003a, b) suggested a $650 \mathrm{bp} 5^{\prime}$ fragment of the mitochondrial cytochrome- $c$ oxidase subunit $1(\operatorname{cox} 1)$ gene as a universal marker or 'DNA barcode' for global biological identification of animal species. Use of this mitochondrial gene has a number of advantages. Firstly, among mitochondrial genes, the coxl gene is one of only two protein-encoding genes [the other encoding cytochrome $b(c y t b)$ ] that are present in all eukaryotes. In addition, it functions homologously in a wide range of eukaryotes, enabling its sequence to be compared across a diverse array of organisms. Secondly, cytochrome-encoding genes such as coxl and cytb are more variable than other commonly studied mitochondrial genes, such as 12S RNA and tRNA genes (Janczewski et al., 1995; Kumazawa \& Nishida, 1993). Therefore, these protein-encoding genes can be used to discriminate closely related species (Hebert et al., 2003b). Thirdly, the coxl gene of various animal phyla is easily amplified using universal primers designed from conserved regions of the gene (Folmer et al., 1994). Fourthly, because mitochondria reproduce by binary fission and without sexual recombination, their genes are less subject to insertions, deletions or other large-scale rearrangements that introduce more ambiguous variation into the sequence. Finally, it has long been recognized that the mitochondrial genome evolves at a faster rate than the nuclear genome and therefore mitochondrial genomic sequences at a particular region will be more informative in differentiating or distinguishing closely related species (Hebert et al., 2003b). Preliminary studies have proven this gene to be a good taxonomic marker for discriminating species of animals such as gastropods (Remigio \& Hebert, 2003), collembolans (Hogg \& Hebert, 2004), mayflies (Ball et al., 2005), flies (Scheffer et al., 2006), moths (Brown et al., 2003), butterflies (Hajibabaei et al., 2006; Hebert et al., 2004a), beetles (Monaghan et al., 2005), ants (Smith et al., 2005), spiders (Barrett \& Hebert, 2005), fishes (Ward et al., 2005) and birds (Hebert et al., 2004b).

Among living organisms, protists have long been recognized as an assemblage of organisms of complex forms and with polymorphic life histories. A majority of them are microscopic, and specific staining procedures and electron microscopy are often required in order to reveal key features for taxonomic identification (Corliss \& Daggett, 1983). So far, a DNA barcoding approach using coxl gene sequences has been applied to identify only a few groups of protists, such as red algae and some ciliate genera (Barth et al., 2006; Lynn \& Strüder-Kypke, 2006; Saunders, 2005). However, among those ciliates examined, only a few species within two genera, Paramecium and Tetrahymena, were investigated.

To examine the usefulness of the cox 1 barcode for ciliate species identification, species of the genus Tetrahymena were investigated. Tetrahymena includes a number of closely related species, both sexual outbreeders and asexual forms. Previous identification of Tetrahymena species has been based on several approaches such as morphology, a combination of ecology and life histories, mating tests, isozyme mobilities and PCR-RFLP (Corliss, 1973; Czapik, 1968; Holz \& Corliss, 1956; Jerome \& Lynn, 1996; Meyer \& Nanney, 1987; Nanney \& McCoy, 1976; Nyberg, 1981). However, because of the close relatedness of some members within the genus, species can often not be discriminated using morphological features, even at the ultrastructural level (Corliss \& Daggett, 1983). Furthermore, several Tetrahymena isolates have long been known that share morphological similarities but are genetically isolated from each other and were initially named as different syngens, and they have proven to be difficult to discriminate without mating tests (Gruchy, 1955). In addition, some Tetrahymena species show phenotypic plasticity in response to different environmental conditions during their polymorphic life cycles, making them even more difficult to identify morphologically and ecologically (Corliss, 1973; StrüderKypke et al., 2001).

Among identification approaches, mating reactivity remains the 'gold standard' to determine conspecificity and to discover new species of Tetrahymena. Using this method, a large number of cryptic species were discovered within the Tetrahymena pyriformis species complex (Elliott, 1970; Gruchy, 1955; Nanney \& McCoy, 1976). However, a complete set of living reference strains is not available and the approach is impossible for amicronucleate strains, which have been known to be common in Tetrahymena (Nanney \& McCoy, 1976). With the advent of molecular techniques, several approaches, such as isozyme mobilities and RFLP, were used to discriminate Tetrahymena species without requiring mating tests. Borden et al. (1977) reported that the most closely related syngens shared an isozyme similarity coefficient of $67 \%$, while the distantly related ones had a coefficient of 0 . This criterion was used to support the establishment of several new Tetrahymena species (Nanney \& McCoy, 1976). However, these identification approaches are now known to have their own limitations: RFLP patterns are identical for several species pairs (Jerome \& Lynn, 1996), while similar polymorphisms among species are shown for isozyme mobilities (Meyer \& Nanney, 1987; Nanney et al., 1998).

Thus, the coxl DNA barcoding approach, which has proven to be useful for identifying species of animals, was chosen to identify Tetrahymena species. Since few DNA barcoding studies have been done on protists so far, it is uncertain whether the $650 \mathrm{bp} 5^{\prime}$ region of the coxl gene, which works well taxonomically for the discrimination of animal species, would be suitable for differentiating ciliated protists. Therefore, in this study, we amplified and sequenced almost the entire length of the $\operatorname{cox} 1$ gene of representatives of 36 Tetrahymena species and six wild isolates of undescribed Tetrahymena species as well as three non-Tetrahymena ciliates that are close allies of 
Tetrahymena, Colpidium campylum, Colpidium colpoda and Glaucoma chattoni. This sampling covered all valid species of this ciliate genus that have been described so far and whose cultures are available. This enabled us to evaluate which part of the gene was the most appropriate diagnostic barcoding region for identifying species of ciliates. In addition, 33 strains of six different Tetrahymena species isolated from different geographical localities were examined to demonstrate that levels of genetic variation within species are sufficiently low to ensure unambiguous identification with the coxl barcode.

\section{METHODS}

Source of samples. Seventy-eight isolates of tetrahymenine ciliates were examined in this study (see Supplementary Table S1 in IJSEM Online). Of 42 taxonomically valid species of Tetrahymena (Fenchel \& Finlay, 2004), 36 are available in culture and at least one isolate of each of these species was selected as a species representative. These species were Tetrahymena americanis, T. asiatica, T. australis, T. bergeri, T. borealis, T. canadensis, T. capricornis, T. caudata, T. corlissi, T. cosmopolitanis, T. elliotti, T. empidokyrea, T. farleyi, T. furgasoni, T. hegewischi, T. hyperangularis, T. leucophrys, T. limacis, T. lwoffi, T. malaccensis, T. mimbres, T. mobilis, T. nanneyi, T. nipissingi, T. paravorax, T. patula, T. pigmentosa, T. pyriformis, T. rostrata, $T$. setosa, T. shanghaiensis, T. silvana, T. sonneborni, T. thermophila, T. tropicalis and T. vorax. The remaining six valid Tetrahymena species, Tetrahymena chironomi, T. dimorpha, T. edaphoni, T. rotunda, T. sialidos and $T$. stegomyiae, were not examined because of the unavailability of their cultures. In addition, six isolates of undescribed Tetrahymena species and three other tetrahymenine species, $C$. campylum, C. colpoda and G. chattoni, were also investigated. Furthermore, among the Tetrahymena species, additional isolates of T. borealis (4), T. Iwoffi (1), T. patula (1), T. pyriformis (4), T. thermophila (3) and T. tropicalis (4) were examined to assess intraspecific sequence divergence. Moreover, the 16 cox 1 sequences available from GenBank for one T. pyriformis and 15 T. thermophila isolates were also included. Detailed information is provided in Supplementary Table S1 for all isolates, including catalogue numbers, designations, localities and GenBank accession numbers.

Culture methods and maintenance. All tetrahymenine ciliates except for the two species of Colpidium were cultured axenically in $10 \mathrm{ml}$ sterile proteose peptone yeast extract (PPYE) medium $(0.5 \mathrm{~g}$ glucose, $2.0 \mathrm{~g}$ proteose peptone, $2.0 \mathrm{~g}$ yeast extract and $400 \mathrm{ml}$ distilled water). The two species of Colpidium were cultured in $10 \mathrm{ml}$ bacterized dried cereal grass leaves (Cerophyl) medium, prepared as follows. Cerophyl $(20 \mathrm{~g})$ was added to $400 \mathrm{ml}$ distilled water and boiled for $10 \mathrm{~min}$. Distilled water was added to compensate for evaporation and the medium was filtered through Whatman no. 1 filter paper. An aliquot of $10 \mathrm{ml}$ of this concentrated medium was transferred into culture test tubes and autoclaved for $20 \mathrm{~min}$ at $121{ }^{\circ} \mathrm{C}$. Ten millilitres of the concentrated Cerophyl medium was diluted with $200 \mathrm{ml}$ distilled water in a sterile flask. Using sterile technique, Enterobacter aerogenes was inoculated into the diluted Cerophyl medium. The bacterized Cerophyl medium was left at room temperature for $24 \mathrm{~h}$ prior to inoculation with Colpidium spp. All ciliate cultures were transferred biweekly and maintained at room temperature using sterile technique.

DNA extraction, amplification and sequencing. In contrast to dead cells and cell debris, which settle on the bottom of the culture tube, healthy cells swim actively just below the surface of the medium. Thus, about $1 \mathrm{ml}$ of this portion of the culture medium containing ciliates was placed in a $1.5 \mathrm{ml}$ microcentrifuge tube. The cells were pelleted by centrifugation at $11000 \mathrm{~g}$ for $5 \mathrm{~min}$. Two DNA extraction protocols, using Chelex beads as described by Walsh et al. (1991) and total nucleic acid purification as specified by EPICENTRE, were performed to yield total genomic DNA of the ciliates. An appropriate amount of DNA template was used in amplification of the coxl gene and the small-subunit (SSU) rDNA using puReTaq Ready-To-Go PCR beads (GE Healthcare).

cox1 gene. Approximately $2000 \mathrm{bp}$ of the mitochondrial coxl gene were amplified by PCR using the forward primer 5 '-ATGTGAGTTGATTTTATAGAGCAGA-3' and the reverse primer 5'-GGDATACCRTTCATTTT-3', which were newly designed in this study. The thermal cycler was programmed as follows: hold at $94{ }^{\circ} \mathrm{C}$ for $4 \mathrm{~min} ; 5$ cycles of denaturation at $94{ }^{\circ} \mathrm{C}$ for $30 \mathrm{~s}$, annealing at $45^{\circ} \mathrm{C}$ for $1 \mathrm{~min}$ and extension at $72{ }^{\circ} \mathrm{C}$ for $105 \mathrm{~s} ; 35$ cycles of denaturation at $94{ }^{\circ} \mathrm{C}$ for $30 \mathrm{~s}$, annealing at $55{ }^{\circ} \mathrm{C}$ for $1 \mathrm{~min}$ and extension at $72{ }^{\circ} \mathrm{C}$ for $105 \mathrm{~s}$; and hold at $72{ }^{\circ} \mathrm{C}$ for $10 \mathrm{~min}$. PCR products corresponding to the expected size were separated by agarose gel electrophoresis, purified using the GENECLEAN kit (Qbiogene) and sequenced in both the forward and reverse directions with an ABI 3730 DNA Analyser using the standard BigDye Terminator version 3.1 cyclesequencing kit using amplification and internal primers. Almost the entire length, about $1821 \mathrm{bp}$, of the coxl gene of 45 species representatives was sequenced, while at least $689 \mathrm{bp}$ of the $5^{\prime}$ region of the coxl gene of 17 additional intraspecific isolates of six Tetrahymena species mentioned previously were sequenced to assess the diagnostic barcoding region.

SSU rDNA. Approximately $2900 \mathrm{bp}$ of an rDNA fragment were amplified using the forward primer A ( $5^{\prime}$-CAACCTGGTTGATCCTGCCAGT- $\left.3^{\prime}\right)$ and the reverse primer C (5'-TTGGTCCGTGTTTCAAGACG-3') (Jerome \& Lynn, 1996; Medlin et al., 1988). The PCR product included the SSU rDNA, internal transcribed spacer (ITS) 1, the 5.8S rDNA, ITS2 and a portion of the large-subunit (LSU) rDNA. The thermal cycler was programmed as follows: hold at $94{ }^{\circ} \mathrm{C}$ for $4 \mathrm{~min}$; 35 cycles of denaturation at $94{ }^{\circ} \mathrm{C}$ for $1 \mathrm{~min}$, annealing at $55{ }^{\circ} \mathrm{C}$ for $90 \mathrm{~s}$ and extension at $72{ }^{\circ} \mathrm{C}$ for $3 \mathrm{~min}$; and hold at $72{ }^{\circ} \mathrm{C}$ for $10 \mathrm{~min}$. PCR products corresponding to the expected size were processed as described above. However, only a $1800 \mathrm{bp}$ region of the SSU rDNA was sequenced and included in further analyses.

The SSU rDNA was amplified and sequenced for 19 tetrahymenine species that were chosen as species representatives and examined in this study but which have not yet been investigated in any previous studies. These species were T. americanis, T. asiatica, T. caudata, T. cosmopolitanis, T. elliotti, T. furgasoni, T. leucophrys, T. limacis, T. lwoffi, T. mimbres, T. nipissingi, T. paravorax, T. shanghaiensis, T. silvana, T. sonneborni, Tetrahymena sp. 1 (Foissner), Tetrahymena sp. 3 (RA9), Tetrahymena sp. 5 (NI) and C. colpoda. In addition, the SSU rDNA of two isolates of T. pyriformis and four isolates of $T$. tropicalis were also amplified and sequenced. Detailed information on these species and isolates is given in Supplementary Table S1.

Sequence analyses. The $\operatorname{cox} 1$ and SSU rDNA sequences were first aligned automatically by CLUSTAL W (Thompson et al., 1994) using the MEGA program version 3.1 (Kumar et al., 2004) and then further refined by eye. The alignments for coxl and SSU rDNA sequences of the examined tetrahymenine ciliates are available as supplementary material in IJSEM Online.

The coxl gene sequences obtained from this study were $1821 \mathrm{bp}$ in length except for that of G. chattoni, which was $1785 \mathrm{bp}$ long. The 1821 nucleotides span positions 52-1872 with reference to the complete coxl genes of $T$. pyriformis and T. thermophila published in GenBank (Brunk et al., 2003; Burger et al., 2000). 
These coxl sequences were then divided into the following five datasets.

Dataset 1 . This dataset comprised the 1821 bp sequences of the cox 1 genes from a representative of each species, for a total of 45 sequences. Thirty-six positions $(1786-1821)$ at the $3^{\prime}$-end of the coxl gene sequence of $G$. chattoni were treated as missing data.

Dataset 2. This dataset comprised only the $5^{\prime}$ half of the $1821 \mathrm{bp}$ sequences of the coxl genes from a representative of each species, for a total of 45 sequences. This region is $912 \mathrm{bp}$ in length.

Dataset 3. This dataset comprised only the $3^{\prime}$ half of the $1821 \mathrm{bp}$ sequences of the coxl genes from a representative of each species, for a total of 45 sequences. This region is $909 \mathrm{bp}$ in length. Thirty-six positions (874-909) at the $3^{\prime}$-end of the coxl gene sequence of $G$. chattoni were treated as missing data.

Dataset 4 . This dataset comprised the 689 bp sequences of the cox 1 genes from a representative of each species, for a total of 45 sequences. This region starts at position 169 with reference to the 1821 sites of our coxl gene sequences and at position 220 with reference to the 2067 sites of the complete $\operatorname{cox} 1$ gene sequence. Compared to animal barcoding regions, the starting position of this 689 bp sequence is in close proximity to the beginning site of the diagnostic barcoding region used for identifying animal species.

Dataset 5. This dataset comprised the 689 bp sequences of the cox 1 genes from all 78 isolates that were included in this study. This is the same region as dataset 4 .

The SSU rDNA of 19 tetrahymenine species and of six isolates was newly sequenced in this study. In addition, another 24 species whose SSU rDNA sequences were available at GenBank were also included in this study. These species are T. australis, T. bergeri, T. borealis, $T$. canadensis, T. capricornis, T. corlissi, T. empidokyrea, T. farleyi, T. hegewischi, T. hyperangularis, T. malaccensis, T. mobilis, T. nanneyi, T. patula, T. pigmentosa, T. pyriformis, T. rostrata, T. setosa, T. thermophila, T. tropicalis, T. vorax, Tetrahymena sp. 6 (Brandl), C. campylum and G. chattoni. Moreover, full sequences of the SSU rDNA of Tetrahymena sp. 2 (CO) and Tetrahymena sp. 4 (SIN), kindly provided by Dr Michaela C. Strüder-Kypke (Department of Integrative Biology, University of Guelph, Canada), were included in our study. Detailed information on these species and isolates is provided in Supplementary Table S1. Aligned SSU rDNA sequences of all 45 species representatives were constructed as a dataset for sequence divergence calculation. This nucleotide dataset was 1650 positions in length and included a few gaps and some ambiguous characters. Exclusion of these gaps and ambiguous positions gave a total of 1639 sites, which were used in sequence divergence analyses. In addition, SSU rDNA sequences of two T. pyriformis isolates and four $T$. tropicalis isolates were added to the 45-sequence tetrahymenine SSU rDNA alignment to illustrate phylogenetic relationships among these organisms.

Sequence divergences were calculated for each dataset using the Kimura two-parameter (K2P) distance model (Kimura, 1980). A neighbour-joining (NJ) phylogenetic tree was inferred from genetic distances of coxl sequences calculated by DNADIST with the K2P model of sequence evolution using PHYLIP version 3.65 (Felsenstein, 2004; Saitou \& Nei, 1987). Using G. chattoni as the outgroup species, this tree-building approach was performed on the dataset of $689 \mathrm{bp}$ cox 1 gene sequences of 78 tetrahymenine ciliates and the dataset of 1639 bp SSU rDNA sequences of 51 tetrahymenine ciliates to provide an illustration of the patterning of divergence between and within species. In addition, 1000 bootstrap resamplings were carried out using SEQBOOT to determine confidence levels of deduced relationships. CONSENSE within the PHYLIP package was used to construct a consensus tree.

\section{RESULTS AND DISCUSSION}

With tetrahymenine coxl-specific primers, the coxl gene was amplified and recovered for all tetrahymenine ciliates that were examined in this study. However, because of considerable divergence in the coxl gene of G. chattoni, as indicated by its high percentage sequence divergence, our internal primers that were used to sequence toward the $3^{\prime}$ region of the gene could not sequence that area, leaving $36 \mathrm{bp}$ unavailable. Therefore, only $1785 \mathrm{bp}$ of the coxl gene was obtained from G. chattoni. Alignment of the entire length of $1821 \mathrm{bp}$ of coxl sequences of all 45 species representatives was straightforward as there were no insertions and no deletions, corroborating research on other organisms (Hebert et al., 2003b; Mardulyn \& Whitfield, 1999; Ward et al., 2005).

\section{Nucleotide composition}

Mean frequencies of thymine $(\mathrm{T})$, cytosine $(\mathrm{C})$, adenine $(\mathrm{A})$ and guanine $(\mathrm{G})$ and molar percentage $\mathrm{G}+\mathrm{C}$ content for the SSU rDNA of examined tetrahymenines are in the same range as in other ciliates (Elwood et al., 1985; Sogin \& Elwood, 1986; Schlegel et al., 1991). Mean base frequencies and G+C and $\mathrm{A}+\mathrm{T}$ contents of the coxl gene for each genus were similar in five different datasets of the gene, as listed in Supplementary Table S2 in IJSEM Online. Relative nucleotide frequencies for the coxl genes of the examined tetrahymenine species were $38.4-43.1 \mathrm{~mol} \%$ for $\mathrm{T}, 11.0-13.6 \mathrm{~mol} \%$ for $\mathrm{C}$, 30.5$33.6 \mathrm{~mol} \%$ for A and $13.9-15.6 \mathrm{~mol} \%$ for G, yielding mean $\mathrm{G}+\mathrm{C}$ and $\mathrm{A}+\mathrm{T}$ contents of $25.2-29.2$ and $70.8-74.8 \mathrm{~mol} \%$, respectively. The $\mathrm{G}+\mathrm{C}$ content of the 1821 bp coxl gene sequences was similar among the three tetrahymenine genera, with a mean of $26.7 \mathrm{~mol} \%$, and lower than that of the cox 1 gene of Paramecium aurelia, which is $41.8 \mathrm{~mol} \%$ (Burger et al., 2000). The $\mathrm{G}+\mathrm{C}$ content of coxl genes of tetrahymenine ciliates is considerably different from that of animal coxl genes: the $\mathrm{G}+\mathrm{C}$ content of several orders of insects is about $35 \mathrm{~mol} \%$ (Hebert et al., 2003b), while that of 207 species of Australian fish ranges from 42 to $47 \mathrm{~mol} \%$ (Ward et al., 2005). This G $+\mathrm{C}$ content is also characteristic of the nucleotide composition of the entire mitochondrial genomes of T. pyriformis and T. thermophila, which show low $\mathrm{G}+\mathrm{C}$ contents, of 21.3 and $20.7 \mathrm{~mol} \%$, respectively (Brunk et al., 2003; Burger et al., 2000), considerably lower than the $41.2 \mathrm{~mol} \% \mathrm{G}+\mathrm{C}$ of the P. aurelia mitochondrial genome (Cummings, 1992). A search was also carried out for stop codons of the ciliate mitochondrial genomes, UAA and UAG, which encode glutamine in the ciliate nuclear genomes; UGA was excluded as it encodes tryptophan in ciliate mitochondrial genomes (Brunk et al., 2003). These stop codons were not observed in any of the amplified coxl gene sequences, demonstrating that these were fully functional mitochondrial coxl gene sequences.

\section{Sequence analyses for cox1 and SSU rDNA}

Sequence analyses for the cox 1 gene. Mean sequence divergences of all 45 species representatives analysed from 
Table 1. Overall, within-genus and between-genera sequence divergence based on the K2P model

Results from comparisons of the 689 bp coxl barcoding dataset and the 1639 bp SSU rDNA dataset of 45 tetrahymenine species representatives examined in this study are shown. Genus T, 42 species of Tetrahymena; genus C, two species of Colpidium; genus G, one species of Glaucoma. For the SSU rDNA, sequence divergence was calculated with pairwise or complete deletion in effect, as shown. NC, Not calculated.

\begin{tabular}{|c|c|c|c|c|c|c|c|c|}
\hline \multirow[t]{3}{*}{ Gene } & \multirow{3}{*}{$\begin{array}{c}\text { Nucleotide } \\
\text { positions }(n)\end{array}$} & \multicolumn{7}{|c|}{ Sequence divergence $(\%)($ mean \pm SEM $)$} \\
\hline & & \multirow[t]{2}{*}{ Overall } & \multicolumn{3}{|c|}{ Within-genus } & \multicolumn{3}{|c|}{ Between-genera } \\
\hline & & & Genus $\mathrm{T}$ & Genus C & Genus G & Genera $\mathrm{T}$ and $\mathrm{C}$ & Genera $\mathrm{T}$ and $\mathrm{C}$ & G Genera C and G \\
\hline \multirow{3}{*}{$\begin{array}{l}\operatorname{cox} 1 \\
\text { SSU rDNA }\end{array}$} & 689 & $11.13 \pm 0.78$ & $10.47 \pm 0.74$ & $12.82 \pm 1.46$ & NC & $13.13 \pm 0.98$ & $20.31 \pm 1.59$ & $21.19 \pm 1.80$ \\
\hline & 1639 (pairwise) & $1.71 \pm 0.16$ & $1.39 \pm 0.15$ & $3.41 \pm 0.45$ & $\mathrm{NC}$ & $4.05 \pm 0.42$ & $3.48 \pm 0.42$ & $3.85 \pm 0.39$ \\
\hline & 1639 (complete) & $1.56 \pm 0.16$ & $1.24 \pm 0.16$ & $3.26 \pm 0.44$ & NC & $3.87 \pm 0.42$ & $3.41 \pm 0.37$ & $3.76 \pm 0.42$ \\
\hline
\end{tabular}

three different cox1 datasets, including $1821 \mathrm{bp}$, the $912 \mathrm{bp}$ $5^{\prime}$ half and the 909 bp $3^{\prime}$ half, were closely similar, ranging from $10.59 \pm 0.61$ to $11.14 \pm 0.52 \%$ (mean \pm SEM), as shown in Supplementary Table S3. Starting at position 169 with reference to 1821 sites, about 689 bp in the $5^{\prime}$ half of the cox 1 gene were selected as the diagnostic barcoding region. The first portion of about $240 \mathrm{bp}$ and the last portion of about $90 \mathrm{bp}$ in this $689 \mathrm{bp}$ region are comparable to the beginning part and the middle part of $650 \mathrm{bp}$ animal barcodes, respectively. However, the middle portion of about $360 \mathrm{bp}$ of the $689 \mathrm{bp}$ tetrahymenine barcode is an insert unique to the ciliate mitochondrial coxl gene (Ziaie \& Suyama, 1987). The mean sequence divergence value calculated from the 689 bp barcoding region between species pairs for the 45 species representatives was $11.13 \pm 0.78 \% \quad$ (Table 1 ). This divergence value was very similar to those of the three other regions, indicating that any parts of the cox 1 gene can be used as a diagnostic barcode to discriminate between the tetrahymenine species examined. Furthermore, 983 of 990 interspecific pairwise comparisons based on the barcoding region showed more than $2 \%$ sequence divergence (Fig. 1). Among these pairwise comparisons, the following seven species pairs showed apparently low values, ranging from 0 to $1.17 \%$ : T. canadensis ATCC ${ }^{\circledR} 30368^{(\mathrm{M})}$ and T. rostrata $\operatorname{ATCC}^{\circledR} 30770^{\circledR i}(0.73 \%)$, T. furgasoni ATCC $^{\circledR} 30006^{(\mathrm{II}}$ and T. lwoffi $(1630 / 1 \mathrm{G})(0 \%)$, T. nanneyi ATCC ${ }^{\circledR} 50071^{\mathrm{IM}}$ and T. nipissingi ATCC ${ }^{\circledR} 30837^{(\mathbb{I})}(0.29 \%)$, T. pyriformis ATCC $\left.^{\circledR} 30005^{(i i}\right)$ and T. setosa ATCC $^{\circledR} 30782^{(\mathrm{II}}(0 \%)$, Tetrahymena sp. 2 (CO) and Tetrahymena sp. 3 (RA9) $(0.15 \%)$, Tetrahymena sp. 2 (CO) and Tetrahymena sp. 5 (NI) $(1.17 \%)$ and Tetrahymena sp. 3 (RA9) and Tetrahymena sp. 5 (NI) (1.02\%) (Fig. 1). Analyses of percentage sequence divergences of $1821 \mathrm{bp}$, the $912 \mathrm{bp} \mathrm{5}$ half and the $909 \mathrm{bp} \mathrm{3'}$ half for these species pairs showed similar results. However, there were no differences in sequence divergence values in the $5^{\prime}$ and $3^{\prime}$ halves between Tetrahymena sp. 2 (CO) and Tetrahymena sp. 3 (RA9) (both $0.22 \pm 0.16 \%$ ) and between T. furgasoni ATCC ${ }^{\circledR}$ $30006^{\mathrm{im}}$ and T. lwoffi (1630/1G) (both $0 \%$ ).

All 42 species of Tetrahymena, two species of Colpidium and $G$. chattoni were grouped by genus. Within-genus sequence divergence values for Tetrahymena and Colpidium were approximately 10 and $13 \%$, respectively, in all four different $\operatorname{cox} 1$ datasets. Calculation of between-genera sequence divergence based on cox 1 gene sequences showed that Tetrahymena is more genetically related to Colpidium than to Glaucoma (Table 1 and Supplementary Table S3).

Calculated from the 689 bp barcoding region, mean values ( \pm SEM) for sequence divergences among five isolates of $T$. borealis, two isolates of $T$. lwoffi, two isolates of T. patula, six isolates of $T$. pyriformis, 19 isolates of $T$. thermophila

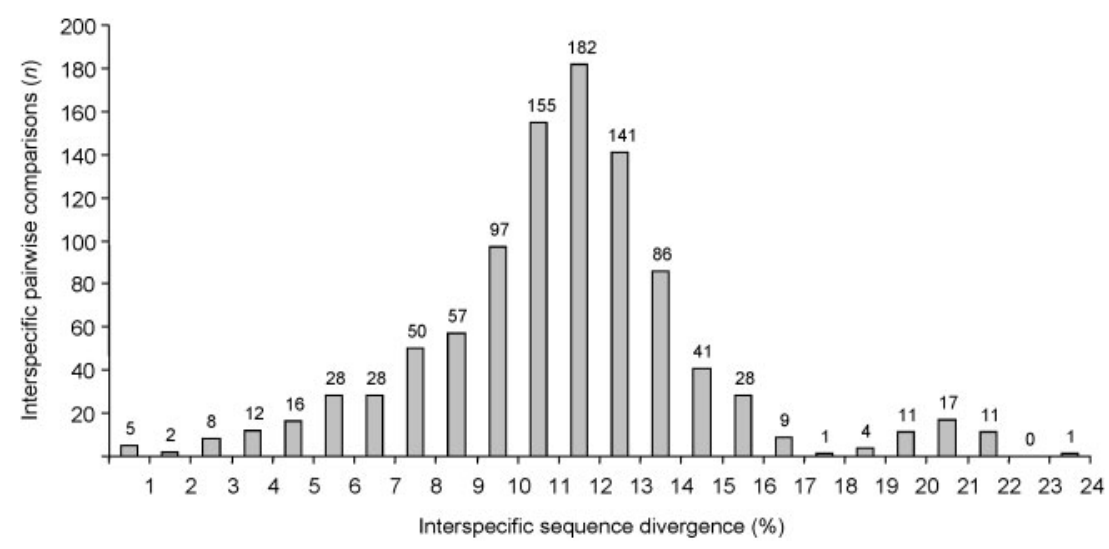

Fig. 1. Distribution of interspecific pairwise sequence divergence based on the $689 \mathrm{bp}$ cox 1 barcoding region of 45 tetrahymenine species representatives, showing that a majority of pairwise comparisons have more than $2 \%$ sequence divergence. 
and five isolates of $T$. tropicalis ranged from 0 to $9.07 \pm 0.83 \%$ (Fig. 2). Among these six species, conspecific isolates of T. borealis, T. lwoffi, T. patula and T. thermophila showed unproblematic results in that they showed $<1 \%$ intraspecific sequence divergence, whereas some conspecific isolates of $T$. pyriformis and $T$. tropicalis showed considerably higher sequence divergences, leading to suspicion of the validity of cultures and/or the status of the isolates of these species.

The mean sequence divergence of individuals within species was $0.95 \%$, compared with $10.47 \%$ between species within the genus Tetrahymena (Table 1). Therefore, there is about 11-fold more variation among congeneric species than among conspecific isolates. Exclusion of all isolates of species with high intraspecific sequence divergences (i.e. $T$. pyriformis and T. tropicalis) reduced this mean intraspecific sequence divergence to $0.18 \%$. This increased the value to about 58.2-fold more variation among congeneric isolates than among conspecific ones. In previous 'barcode of life' studies, a difference in relative sequence divergence of about an order of magnitude is typical between intra- and interspecific comparisons. For example, congeneric sequence divergences are 18 and 25 times greater than conspecific sequence divergences for North American birds (Hebert et al., 2004b) and Australian fishes (Ward et al., 2005), respectively.

The within-species groupings showed a low degree of genetic distance, as represented by short branch length in the 689 bp $\operatorname{cox} 1 \mathrm{NJ}$ tree, and were generally supported by $100 \%$ bootstrap values (Fig. 3). However, conspecific isolates of $T$. pyriformis and $T$. tropicalis showed high sequence divergence values, explaining the interspersion of isolates of these two species on the NJ tree (Fig. 3). Four of

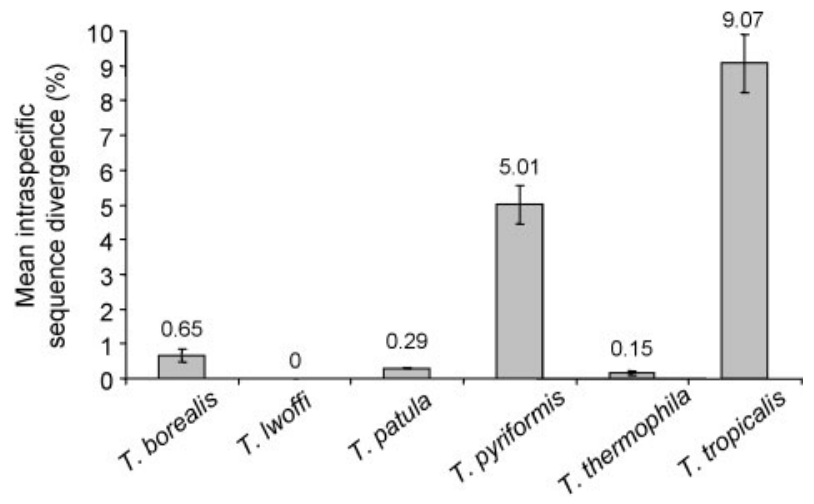

Fig. 2. Intraspecific sequence divergence (\%, mean \pm SEM) of $T$. borealis, T. Iwoffi, T. patula, T. pyriformis, T. thermophila and T. tropicalis calculated from the $689 \mathrm{bp} \operatorname{cox} 1$ barcoding region. Intraspecific isolates of $T$. pyriformis and $T$. tropicalis showed considerably higher sequence divergence values when compared with those of the remaining four species, suggesting the presence of cryptic species or misidentification or contamination of cultures. six isolates of $T$. pyriformis were clustered together with $70.6 \%$ bootstrap support, but separately from the other two isolates (Fig. 3). In addition, T. setosa ATCC ${ }^{\mathbb{R}} 30782^{(i \mathbb{}}$ and T. tropicalis ATCC ${ }^{\mathbb{R}} 205060^{(1 \times)}$ were also clustered with this T. pyriformis clade with $100 \%$ bootstrap support in the $\mathrm{NJ}$ analyses (Fig. 3). The remaining two T. pyriformis isolates, T. pyriformis ATCC $^{\circledR} 205038^{(i m}$ and T. pyriformis ATCC $^{\circledR} 205062^{(}{ }^{\circledR}$, were grouped with low bootstrap support with the main $T$. pyriformis clade, but on a separate well-supported clade with $79.8 \%$ bootstrap support (Fig. 3). Moreover, the terminal branches of these two T. pyriformis isolates appeared to be long, showing larger genetic distances and suggesting the possibilities of their status as novel species.

Interspersion of the other four $T$. tropicalis isolates was nearly complete: $T$. tropicalis ATCC ${ }^{\circledR} 205083^{(\mathbb{m}}$ and $T$. tropicalis ATCC $^{\circledR} 205097^{(\mathbb{m}}$ were clustered with Tetrahymena sp. 2 (CO), Tetrahymena sp. 3 (RA9) and Tetrahymena sp. 5 (NI) with $99.4 \%$ bootstrap support; $T$. tropicalis ATCC ${ }^{\circledR} 30276^{(10}$ was grouped with T. mobilis ATCC $^{\mathbb{B}}$ PRA- $174^{(1 \times}$ with $87.6 \%$ bootstrap support; and, finally, T. tropicalis ATCC ${ }^{\circledR} 205156^{(i}$ was placed close to $T$. empidokyrea ATCC ${ }^{\circledR} 50595^{\circledR}$ and near G. chattoni (Fig. 3).

Sequence divergence analyses of different portions of the $1821 \mathrm{bp}$ region showed that the $689 \mathrm{bp} 5^{\prime}$-region could be used effectively as a DNA barcode for identifying Tetrahymena spp., as supported by very similar values of percentage sequence divergence calculated from the four regions of the coxl gene. A comparable region of the coxl gene has been used extensively as a diagnostic barcoding region in identifying species for several animal groups, as noted above.

Sequence analyses for SSU rDNA. The 1639 bp of SSU rDNA were included in the sequence divergence analysis. Calculation of 1599 positions of the gene, excluding gaps and missing data, for 45 species representatives showed a mean sequence divergence of $1.56 \pm 0.16 \%$. However, the mean value of sequence divergence for the 1639 sites increased slightly to $1.71 \pm 0.16 \%$ when gaps and missing data were deleted in a pairwise manner (Table 1). The sequence divergence values calculated from the SSU rDNA were considerably lower than those obtained from the cox 1 gene in every analysis (Table 1). A majority of interspecific pairwise comparisons based on SSU rDNA showed 0-2\% sequence divergence (Fig. 4). Except for the two species pairs Tetrahymena sp. 2 (CO) and Tetrahymena sp. 3 (RA9) and Tetrahymena sp. 3 (RA9) and Tetrahymena sp. 5 (NI), which both showed $0.06 \%$ sequence divergence in SSU rDNA, the other five species pairs that showed a low degree of sequence divergence based on coxl gene sequences had $0 \%$ sequence divergence between their SSU rDNAs.

Certain other species pairs could not be discriminated using the SSU rDNA sequences, showing $0 \%$ sequence divergence (Fig. 4). However, these species pairs showed some degree of sequence divergence based on coxl 


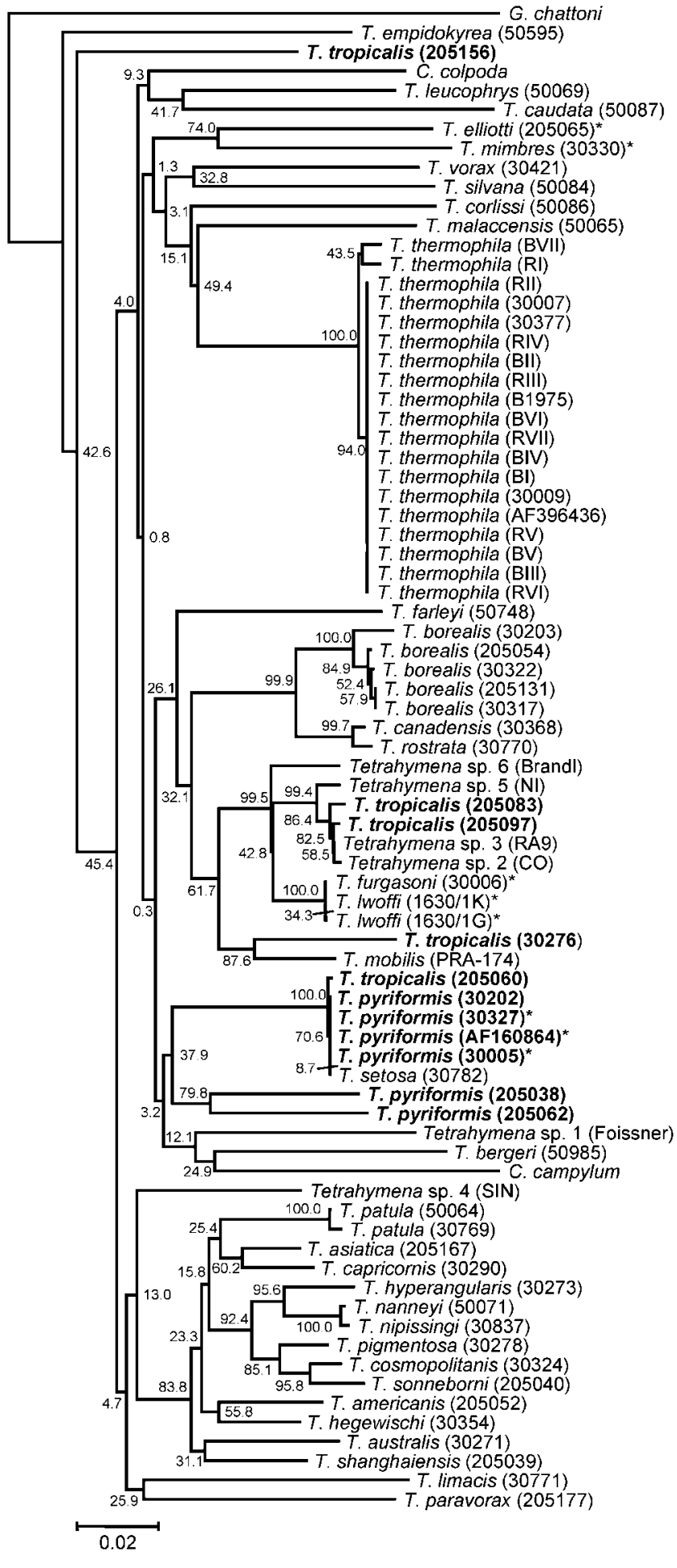

sequences, such as $5.30 \%$ between $T$. americanis ATCC ${ }^{\mathbb{R}}$ $205052^{(\mathrm{II})}$ and T. hegewischi ATCC ${ }^{\circledR} 30823^{(\mathrm{M})}, 4.70 \%$ between T. asiatica ATCC ${ }^{\circledR} 205167^{(\mathrm{IM})}$ and T. capricornis ATCC $^{\circledR} \quad 30291^{\circledR i}, 4.01 \%$ between $T$. borealis ATCC $^{\circledR}$ $205012^{(\mathrm{IM})}$ and T. canadensis ATCC ${ }^{\circledR} 30368^{(\mathrm{II})}$ and $4.43 \%$ between $T$. cosmopolitanis ATCC $^{\circledR} 30324^{\circledR \mathrm{IM}}$ and $T$. hyperangularis ATCC ${ }^{\circledR} 30273^{(\mathrm{I})}$. This result indicated that SSU rDNA sequences are not sufficiently variable to
Fig. 3. NJ tree inferred from $689 \mathrm{bp}$ of the diagnostic barcoding region of the cox 1 gene for all 78 tetrahymenine species isolates. Genetic distance calculation was based on the K2P model of sequence evolution. Branch lengths separating taxa represent genetic distances. Bar, 0.02 nucleotide substitutions per site. Percentage bootstrap support for taxa within the $T$. pyriformis and T. thermophila clades, which are not shown in the figure, were typically lower than 20 and $5 \%$, respectively. Values are percentages of bootstrap support from 1000 resamplings for the $\mathrm{NJ}$ analysis. Because of the interspersion of intraspecific isolates of T. pyriformis and T. tropicalis, those strains are labelled in bold. Amicronucleate species and strains (if known) are labelled with asterisks $\left({ }^{*}\right)$.

differentiate tetrahymenine ciliates, especially in closely related species, and also confirmed the usefulness of the cox1 gene in identifying Tetrahymena species.

\section{Comparison of intraspecific sequence divergence in Tetrahymena and other organisms}

The low intraspecific sequence divergence values for all four unproblematic Tetrahymena species examined ( $T$. borealis, T. Iwoffi, T. patula and T. thermophila) are similar to those calculated for the barcoding region of various groups of animals. For example, mean values of withinspecies sequence divergence are $0.39 \%$ in Australian fishes (Ward et al., 2005), $0.43 \%$ in North American birds (Hebert et al., 2004b), $1 \%$ in mayflies (Ball et al., 2005) and $<1 \%$ in springtails (Hogg \& Hebert, 2004), lepidopterans (Hajibabaei et al., 2006; Hebert et al., 2003b) and several arachnid species (Barrett \& Hebert, 2005). These results are consistent with intraspecific divergences of mitochondrial genes hardly greater than $2 \%$ and most less than $1 \%$ (Avise, 2000). However, several species of animals, as well as some protists, have been reported to have high degrees of intraspecific divergence. For example, values of 5 and

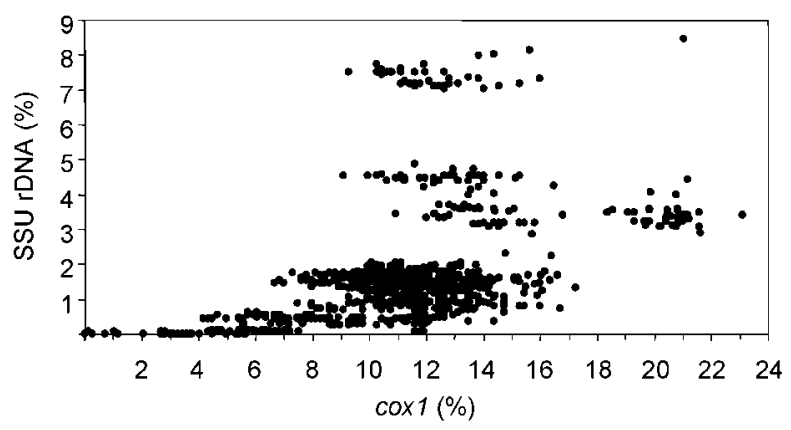

Fig. 4. Relationship between interspecific sequence divergences of the 689 bp cox 1 barcoding region and 1639 bp SSU rDNA for 45 tetrahymenine species representatives. Note that the cox1 gene provides better discrimination among these tetrahymenine species. 
$13 \%$ within-species divergence were reported in the collembolans Sminthurides malmgreni and Folsomia quadrioculata, respectively (Hogg \& Hebert, 2004). Two specimens of the shortnose chimaera Hydrolagus novaezelandiae showed $14.08 \%$ intraspecific distance (Ward et al., 2005). A single individual of the mayfly Maccaffertium modestum showed $13.7 \%$ intraspecific divergence from the other specimens examined, implying the presence of a cryptic species complex as suggested by some behavioural evidence (Ball et al., 2005). In addition, intraspecific divergence values of the ciliates Paramecium caudatum and Paramecium multimicronucleatum were 7 and $9.5 \%$, respectively (Barth et al., 2006). However, Barth et al. (2006) suspected that their intraspecific isolates of these nominate Paramecium species might belong to more than one syngen or biological species and suggested future investigation of these isolates by mating reactivities to determine whether they belong to known or novel syngens.

Intraspecific sequence divergence analyses for $T$. pyriformis. When Nanney \& McCoy (1976) established nominal species for the syngens of Tetrahymena, they did not at the same time establish holotype strains for each species. Therefore, we suggest that the T. pyriformis strain phenoset A ATCC ${ }^{\mathbb{R}} 30327^{\circledR \mathbb{(}}$ be established as the holotype strain based on its original isolation in 1922 by Professor Dr André Lwoff (ATCC catalogue). With this isolate as the type for the species, four T. pyriformis isolates (an unnamed isolate represented by GenBank accession no. AF160864, ATCC $^{\circledR} 30327^{(i x}$, ATCC $^{\circledR} 30005^{(i m}$ and ATCC $^{\circledR}$ $\left.30202^{(i i}\right)$, T. setosa HZ-1 (=ATCC ${ }^{\circledR} 30782^{(\mathbb{i}}$ ) and T. tropicalis G1-R (=ATCC $\left.{ }^{\circledR} 205060^{(i \times}\right)$ clustered together with $100 \%$ bootstrap support in the cox $1 \mathrm{NJ}$ tree: these six strains differed from each other by less than $0.2 \%$ in their coxl gene sequences. The relatedness between $T$. pyriformis and $T$. setosa has been suggested by several previous studies. For example, there are no nucleotide differences in the 5.8S, SSU rDNA or partial LSU rDNA sequences between T. pyriformis and T. setosa (Nanney et al., 1989; Preparata et al., 1989; Strüder-Kypke et al., 2001). However, this species pair showed an isozyme similarity coefficient of only $62 \%$, indicating their independent species status based on the isozyme species criterion (Meyer \& Nanney, 1987; Nanney et al., 1989).

In contrast to our study, previous studies have not shown a close relationship between $T$. tropicalis G1-R $\left(=\right.$ ATCC $^{\circledR}$ $\left.205060^{(\mathrm{m}}\right)$ and strains of T. pyriformis. Referred to as strain G1-R, T. tropicalis ATCC $^{\circledR} 205060^{\circledR}$ showed isozyme mobilities distinct from those of other strains of Tetrahymena, including strains of $T$. pyriformis (Borden et al., 1973a). In addition, based on sequences of the D2 domain of the LSU rDNA, T. tropicalis ATCC ${ }^{\circledR} 205060^{(1 \times}$ was grouped together with other $T$. tropicalis isolates, but separately from the ' $T$. pyriformis' cluster (Nanney et al., 1998). However, our SSU rDNA sequence corroborated the result from the coxl data, confirming the clustering of $T$. tropicalis ATCC ${ }^{(\mathbb{R}} 205060^{(\mathbb{0}}$ with T. pyriformis (GenBank accession no. X56171): there was $0 \%$ sequence divergence in the SSU rDNA (data not shown).

Based on coxl gene sequences, deep intraspecific divergence was found between T. pyriformis ATCC ${ }^{\mathbb{R}} 205038^{(\mathbb{1}}$ and T. pyriformis ATCC $^{\circledR} 205062^{(}{ }^{\circledR}$, as represented by $8.46 \%$ genetic distance between these two isolates and the remaining four $T$. pyriformis isolates. However, analysis of sequences of 190 bases of the LSU rDNA showed a close relationship between these two T. pyriformis isolates and other T. pyriformis isolates (Nanney et al., 1998). Given a mean intraspecific sequence divergence value of $<1.0 \%$, these two T. pyriformis isolates showed more than eight times this conspecific divergence value. The incongruence between our study and previous ones may indicate either the presence of cryptic species within $T$. pyriformis or misidentification or contamination of the cultures.

Based on the success of the coxl gene in identifying animal and other Tetrahymena species, our work implies that $T$. setosa HZ-1 (=ATCC $\left.{ }^{\mathbb{R}} 30782^{(\mathbb{i}}\right)$ and T. tropicalis G1-R (=ATCC ${ }^{\circledR} 205060^{(i \mathrm{M}}$ ) should be assigned to T. pyriformis (see below). Analyses of the SSU rDNA to assess the status of T. pyriformis ATCC $^{\circledR} 205038^{(i}{ }^{\circledR}$ and T. pyriformis ATCC $^{\circledR} 205062^{(i \times}$ confirmed their placement, based on coxl sequences, close to $T$. pyriformis (GenBank accession no. X56171), with a mean of $0.04 \%$ sequence divergence in the SSU rDNA for these three strains (data not shown).

Intraspecific sequence divergence analyses for $T$. tropicalis. As indicated by nearly complete interspersion of its conspecific isolates in the $\mathrm{NJ}$ tree, $T$. tropicalis showed a high degree of intraspecific sequence divergence. Again, since Nanney \& McCoy (1976) did not designate a holotype strain for $T$. tropicalis, we suggest that strain TC-105 of T. tropicalis ATCC ${ }^{\circledR} 30276^{(i}{ }^{(1)}$ be chosen as the holotype strain on the basis of its origin from one of the type localities of the species, which are the American tropics and the Pacific islands (Nanney \& McCoy, 1976), and its original isolation from Rio Martin Sanchez, Panama, by A. M. Elliott (Nanney et al., 1998). Given this isolate as the holotype strain, the other four isolates did not show close intraspecific relationships to it based on the coxl gene sequence. This result is consistent with our analyses of SSU rDNA sequences but contradictory to that based on analysis of sequences of 190 bases of the LSU rDNA, which showed a grouping together of all four isolates, T. tropicalis ATCC ${ }^{\mathbb{R}} 30276^{(i \times}$, T. tropicalis ATCC ${ }^{\circledR}$ 205097 ${ }^{(\mathbb{1}}$, T. tropicalis ATCC ${ }^{\circledR} 205060^{(凶 一}$ and T. tropicalis ATCC $^{\circledR} 205083^{(\mathbb{M}}$ (Nanney et al., 1998). In addition, T. tropicalis ATCC ${ }^{\circledR} 205156^{(\mathrm{M}}{ }^{\mathrm{N}}$ was placed distantly from these other T. tropicalis isolates in the $689 \mathrm{bp} \operatorname{cox} 1 \mathrm{NJ}$ tree and confirmed by the SSU rDNA tree, which placed this isolate as a sister taxon of T. empidokyrea ATCC $^{\circledR} 50595^{(i}$ (Fig. 5). These inconsistencies between our study and previous ones may indicate either the presence of cryptic species within T. tropicalis or mislabelling or contamination of the cultures. Amplification and sequencing of the coxl gene of 


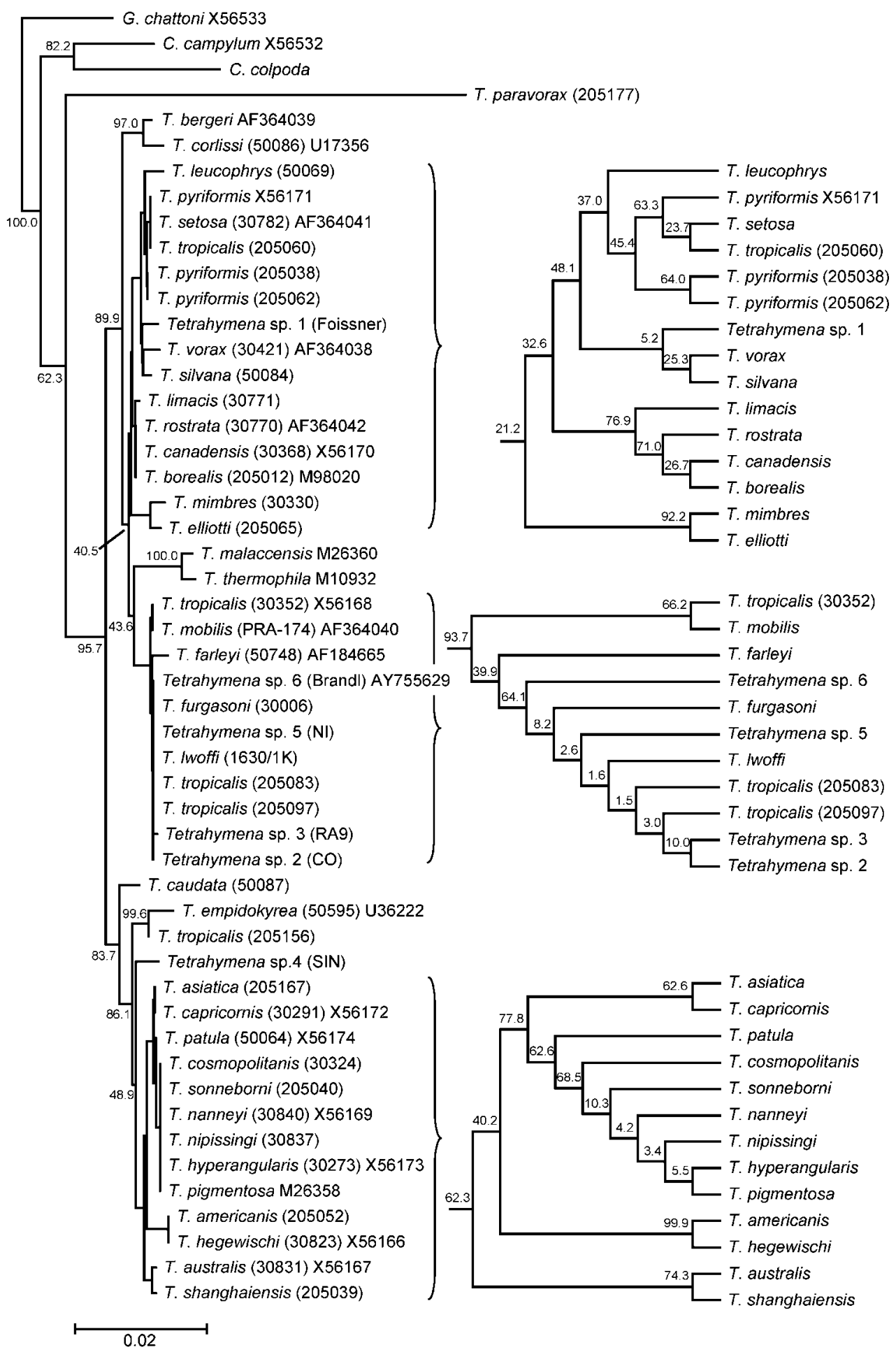

Fig. 5. NJ tree of 51 tetrahymenine species, including 45 species representatives, two additional intraspecific isolates of $T$. pyriformis and four additional intraspecific isolates of $T$. tropicalis, inferred from $1639 \mathrm{bp}$ of the SSU rDNA. Percentage bootstrap values at nodes are based on 1000 resamplings of the data. Magnified clades show the topology more clearly, but percentage bootstrap values at the nodes are typically extremely low. Genetic distance calculation was based on the K2P model of sequence evolution. Branch lengths separating taxa represent genetic distance. Bar, 0.02 nucleotide substitutions per site. 
additional T. tropicalis isolates should be performed to assess its species status.

\section{Comparison of interspecific sequence divergence in Tetrahymena and other organisms}

In general, interspecific coxl sequence divergence values of Tetrahymena spp. are about $10 \%$. This result is similar to the interspecific sequence divergence values calculated from the barcoding region of various groups of animals: mean values of between-species sequence divergence range from 4.41 to $6.02 \%$ in three families of tropical lepidopterans (Hajibabaei et al., 2006), $7.93 \%$ in North American birds (Hebert et al., 2004b), $>8 \%$ in springtails (Hogg \& Hebert, 2004), $9.93 \%$ in Australian fishes (Ward et al., 2005), $16.4 \%$ in arachnid species (Barrett \& Hebert, 2005) and $18 \%$ in mayflies (Ball et al., 2005). Moreover, between-species sequence divergence of 11 animal phyla ranged from 6.6 to $15.7 \%$ with the exception of some cnidarians, which showed only $1 \%$ interspecific sequence divergence (Hebert et al., 2003a). Although a majority of interspecific sequence divergence values were normally many times greater than intraspecific ones, several congeneric pairs have been found to exhibit a low degree of interspecific divergence, sometimes lower than $2 \%$. For example, 13 species in four bird genera, Larus, Haematopus, Corvus and Anas, showed interspecific genetic distances lower than $1.25 \%$ (Hebert et al., 2004b).

In our study, there were several Tetrahymena species pairs that showed $<1 \%$ interspecific sequence divergence calculated from the $689 \mathrm{bp}$ barcoding region. These species pairs are T. canadensis ATCC ${ }^{\mathbb{R}} 30368^{\circledR}$ and T. rostrata ATCC $^{\circledR} 30770^{(m)}$, T. furgasoni ATCC $^{\circledR} 30006^{\circledR}$ and T. lwoffi $(1630 / 1 \mathrm{G})$, T. nanneyi ATCC $^{\circledR} 50071^{(i \times}$ and $T$. nipissingi ATCC $^{\circledR} 30837^{(凶}$, T. pyriformis ATCC $^{\circledR} 30005^{(\mathbb{M}}$ and T. setosa ATCC ${ }^{\circledR} 30782^{(i \times}$, Tetrahymena sp. 2 (CO) and Tetrahymena sp. 3 (RA9), Tetrahymena sp. 2 (CO) and Tetrahymena sp. 5 (NI) and Tetrahymena sp. 3 (RA9) and Tetrahymena sp. 5 (NI).

Taxonomic relationship of $T$. canadensis and $T$. rostrata. Formerly known as syngen 7 of the T. pyriformis species complex, T. canadensis is morphologically indistinguishable but reproductively isolated from other members of the T. pyriformis species complex and, based on isozyme data, the organism was established as a named species by Nanney \& McCoy (1976). T. rostrata was first described as Paraglaucoma rostrata by Kahl (1926). Corliss (1952) transferred this species to the genus Tetrahymena as $T$. rostrata. On the basis of its capacity to form both reproductive and resting cysts, to exhibit edaphic and parasitic forms and to possess histophagous or parasitic habits, Corliss (1952) established it as the 'type' of the rostrata complex.

The low value of interspecific sequence divergence between T. canadensis ATCC $^{\circledR} 30368^{\circledR}$ and T. rostrata ATCC ${ }^{\circledR}$ $30770^{(i x}$ implies either convergent molecular evolution of these two species, phenotypic morphological variations within a single genetic species, contamination or misidentification of the cultures. Interspecific sequence divergence values inferred from $1821 \mathrm{bp}$ and $689 \mathrm{bp}$ of the coxl gene were $1 \%$ (18 nucleotide differences) and $0.73 \%$ (5 nucleotide differences), respectively. In addition, the 1639 sites of the SSU rDNA sequences were identical. Close relationships between $T$. canadensis and $T$. rostrata were also revealed by several previous molecular studies. For example, based on analysis of 180 sites of $23 \mathrm{~S}$ rRNA gene sequences, no differences were observed (Nanney et al., 1989). In addition, these two species were grouped within riboset $\mathrm{A}$, since identical sequences were also found for $120 \mathrm{bp}$ of the LSU rDNA and $154 \mathrm{bp}$ of the 5.8S rDNA (Preparata et al., 1989). Furthermore, only 3 of 579 bp of the histone H3II/H4II region were different between these two species (Sadler \& Brunk, 1992). Although analysis of isozyme mobility between $T$. canadensis and $T$. rostrata showed a similarity coefficient of $66 \%$, which suggested their discrete but very closely related species status (Borden et al., 1977; Meyer \& Nanney, 1987), all of the other molecular evidence apparently indicates their identity as a single species.

Since we observed neither reproductive nor resting cysts in T. rostrata $\mathrm{ATCC}^{\circledR} 30770^{\circledR}$, misidentification of this culture is likely. New field isolates of T. rostrata demonstrating species-specific characters must be collected to confirm the taxonomic validity and barcode for this species. This will also help us determine whether $T$. canadensis is just a pyriform stage of $T$. rostrata, and the former should then be regarded as a junior synonym of the latter.

Taxonomic relationship of $T$. furgasoni and $T$. Iwoffi. $T$. furgasoni and $T$. lwoffi as well as T. elliotti are all amicronucleate and distinct from T. pyriformis and from each other based on heterogeneous isozyme patterns (Borden et al., 1973a, b). Nanney \& McCoy (1976) established these three isozymically distinct groups as new species and named them after three pioneer tetrahymenologists, Waldo H. Furgason, André Lwoff and Alfred M. Elliott.

The failure to discriminate between T. furgasoni ATCC $^{\circledR}$ $30006^{(i)}$ and T. Iwoffi $(1630 / 1 \mathrm{G})$ was due to the $0 \%$ sequence divergence in both the coxl and SSU rDNA sequences. These two species were assigned to the pyriformis complex and, before formally receiving Latinized binomial names, T. furgasoni was known as two strains of T. pyriformis, GL-5 and GL-10, whereas T. lwoffi was recognized as four strains of T. pyriformis, $\mathrm{PP}, \mathrm{CH}-\mathrm{S}$, GP and H-1 (Borden et al., 1973a; Meyer \& Nanney, 1987). These two groups are isozymically different and were therefore later established as the new species $T$. furgasoni and T. lwoffi by Nanney \& McCoy (1976). Re-examination of isozyme mobilities of T. furgasoni and T. lwoffi by Meyer \& Nanney (1987) showed different results from the previous study by Borden et al. (1973a): these two species then had indistinguishable isozyme patterns. Meyer \& 
Nanney (1987) suggested that they should be synonymized and suppressed the species name $T$. Iwoffi. In addition, a high similarity in cytoskeleton proteins between $T$. furgasoni and T. lwoffi was observed by Williams et al. (1984). Furthermore, since both species lack a micronucleus, a mating test and the production of fertile $\mathrm{F} 1$ could not be performed. Thus, DNA-based identification using coxl gene sequences has supported the synonymous status of these two species. Other isolates of T. furgasoni and $T$. lwoffi (if any) are required in order to support their conspecificity further.

Taxonomic relationship of $T$. pyriformis and $T$. setosa. $T$. setosa, formerly known as T. setifera, was described by Holz \& Corliss (1956) as a new species on the basis of having a caudal cilium at its posterior end. Possession of a caudal cilium by $T$. setosa gives darkly stained granules surrounded by a delicate fibril at the posterior pole of the cell, the so-called polar basal granule (PBG) complex. The species was also distinguished based on its contractile vacuole pores (CVP) compared with those of T. pyriformis: the two CVPs of T. setosa are placed parallel to each other, whereas those of $T$. pyriformis are positioned obliquely to each other.

One nucleotide difference in the coxl gene sequences between T. pyriformis ATCC ${ }^{\circledR} 30005^{(i}$ and T. setosa ATCC $^{\circledR} 30782^{\circledR}$ led to sequence divergence values of only 0.11 and $0 \%$ calculated from the $3^{\prime}$-region and the barcoding region, respectively. In addition, the 1639 sites of their SSU rDNA sequences were identical. This gave rise to the suspicion of two possible scenarios, as discussed below. Firstly, the cultures may have been either mislabelled or contaminated. Secondly, these two tetrahymenines are actually the same genetic species. Observation and staining of starved live cells of T. setosa showed that none had a caudal cilium (data not shown). Cells from the $T$. setosa culture were stained using the Chatton-Lwoff procedure (Corliss, 1953). Fifty silver-stained cells were examined to determine the position of CVPs and the existence of a PBG complex. The parallel CVP type was found in 14 cells $(n=50)$ of the T. setosa culture. The remaining 36 cells had an oblique pattern of CVPs (i.e. $T$. pyriformis-type CVPs). In addition, when the posterior ends of cells were observed, only two cells $(n=12)$ had both a PBG complex and parallel CVPs. The remaining 10 cells had no PBG complex and oblique CVPs (i.e. T. pyriformisspecific characteristics). Although these microscopic observations suggest either that $T$. setosa is polymorphic for these traits or that the culture of $T$. setosa had been contaminated with $T$. pyriformis either prior to submission to the ATCC or at some time during its history, the possibility of them being the same genetic species cannot be ruled out.

As previously mentioned, $T$. setosa was described on the basis of possessing a caudal cilium, arrangement of CVPs and other morphological features. However, a study by Nelsen \& Debault (1978) showed that a caudal cilium could be induced in $T$. pyriformis syngen 1 , later named T. thermophila. Therefore, the use of this feature for taxonomic diagnosis seems uncertain.

Single-cell isolation should be performed to establish a pure T. setosa culture. Observation and staining of live cells should be then carried out to ensure that they truly manifest the T. setosa taxonomic characters described by Holz \& Corliss (1956). Once the pure culture is established, both coxl and SSU rDNA should be reamplified and sequenced to compare with the results presented here. If this yields results identical to ours, $T$. setosa should be considered a junior synonym of $T$. pyriformis, confirming that $T$. setosa might be only a strain of $T$. pyriformis, as stated once by Corliss (1972).

Taxonomic relationship of $T$. nanneyi and $T$. nipissingi. $T$. nanneyi and $T$. nipissingi were described as new biological species on the basis of mating reactivities and isozyme mobilities by Simon et al. (1985) and Nyberg (1981), respectively. Isozyme similarity coefficient values between them are $>62 \%$ (Meyer \& Nanney, 1987; Simon et al., 1985). In addition, Nyberg (1981) found a correlation between temperature tolerance and Tetrahymena species and used this species-specific correlation as a supporting criterion to describe new Tetrahymena species such as $T$. hegewischi, T. nipissingi and T. sonneborni. D. Nyberg (personal communication) has suggested that the following strains be established as holotypes: T. hegewischi KP7 (=ATCC $\left.{ }^{\mathbb{R}} 30832^{\circledR i}\right)$, T. nanneyi LB2 $\left(=\right.$ ATCC $^{\mathbb{R}}$ 50071 $\left.{ }^{(i i}\right)$, T. nipissingi X2-AM $\left(=\right.$ ATCC $\left.^{\circledR} 30837^{(\mathbb{i}}\right)$ and $T$. sonneborni $\mathrm{EA} 2\left(=\mathrm{ATCC}{ }^{\circledR} 30834^{(}{ }^{\circledR}\right)$. In this study, holotype cultures of T. nanneyi and T. nipissingi were examined.

Interspecific sequence divergences lower than $1 \%$ for the coxl gene have rarely been found. This phenomenon was observed in our study of T. nanneyi and T. nipissingi. The genetic distance between these two species is $<0.33 \%$ based on coxl gene sequences, demonstrating their close relationship. However, nuclear gene sequences of $T$. nanneyi and T. nipissingi are identical for several genes, for example a partial sequence of the $23 \mathrm{~S}$ rRNA gene (Preparata et al., 1989) and the entire SSU rDNA. Although molecular data showed great similarities between these species, reproductive isolation from each other and other species of Tetrahymena confirms their status as true biological species (Nyberg, 1981; Simon et al., 1985). However, this close relationship between $T$. nanneyi and $T$. nipissingi remains suspicious in light of several lines of evidence. When Nyberg (1981) described T. nipissingi as a new biological species, he also found two other Tetrahymena isolates of a new mating group numbered 15: WX0 and XQ5. In his mating reactivity experiment, Nyberg (1981) refrained from establishment of these two isolates as a new species since crossing between them failed to produce viable progeny. In addition, Nyberg (1981) reported the observation of mating reactivity between strains of group 15 and T. nipissingi by E. Simon, although mating reactivity between them had not been repeatable. 
Subsequently, viable immature progeny were produced by crossing Tetrahymena strain LB2 and isolates of Nyberg's group 15, providing corroborative evidence of a new biological species. This led Simon et al. (1985) to establish a new species, $T$. nanneyi. Given the close molecular relatedness between $T$. nanneyi and $T$. nipissingi from previous studies and our own and the evidence mentioned above, the close relationships between these two species may indicate either a recent divergence between $T$. nanneyi and $T$. nipissingi or that these two ciliates belong to the same species.

In order to validate the biological species status of $T$. nanneyi and T. nipissingi, additional strains from culture collections and nature should be thoroughly examined using the coxl gene and SSU rDNA. Since the isolate of $T$. nipissingi X2-AM $\left(=\right.$ ATCC $\left.^{\circledR} 30837^{(}{ }^{\circledR}\right)$ that was examined in this study was only one representative of the species, other isolates, such as $T$. nipissingi XK $2\left(=\mathrm{ATCC}^{\mathbb{R}}\right.$ $\left.205160^{(i i}\right), \quad$ X13-R1 $\quad\left(=\right.$ ATCC $\left.^{\circledR} 30838^{(i \times}\right), \quad$ X32H3 $\left(=\right.$ ATCC $\left.^{\circledR} 205029^{(\mathbb{i}}\right)$ and X7E3 $\left(=\right.$ ATCC $\left.^{\circledR} 205091^{(\mathbb{M}}\right)$, should particularly be examined. In addition, other isolates of $T$. nanneyi [i.e. the isolate strains XQ5 $\left(=\right.$ ATCC $^{\mathbb{R}}$ $\left.50067^{(\mathbb{i}}\right)$ and WX0 $\left(=\right.$ ATCC $\left.^{\circledR} 205090^{(\mathbb{i}}\right)$ ] that were originally used in describing this species should also be investigated.

Taxonomic relationships among undescribed Tetrahymena species. In our study, six undescribed species, Tetrahymena sp. 1 (Foissner), Tetrahymena sp. 2 (CO), Tetrahymena sp. 3 (RA9), Tetrahymena sp. 4 (SIN), Tetrahymena sp. 5 (NI) and Tetrahymena sp. 6 (Brandl), were examined with the aim of identifying and assigning them to a nominal species using the DNA-based identification criteria of the 689 bp cox 1 barcoding region.

Based on the 689 bp coxl gene sequences, Tetrahymena sp. 1 (Foissner), Tetrahymena sp. 4 (SIN), and Tetrahymena sp. 6 (Brandl) showed considerable genetic distances of 11.47, 9.71 and $9.16 \%$, respectively, from other Tetrahymena species, while, based on SSU rDNA sequences, Tetrahymena sp. 1 (Foissner), Tetrahymena sp. 4 (SIN) and Tetrahymena sp. 6 (Brandl) showed a lower evolutionary distance, 1.18, 1.35 and $1.11 \%$, respectively, from other Tetrahymena species. Furthermore, these three undescribed Tetrahymena showed considerable coxl sequence divergence from each other: $11.60 \%$ between Tetrahymena sp. 1 (Foissner) and Tetrahymena sp. 4 (SIN), $9.76 \%$ between Tetrahymena sp. 1 (Foissner) and Tetrahymena sp. 6 (Brandl) and $8.77 \%$ between Tetrahymena sp. 4 (SIN) and Tetrahymena sp. 6 (Brandl). In addition, these three species did not cluster together in the $\operatorname{cox} 1 \mathrm{NJ}$ tree. Tetrahymena sp. 1 (Foissner) and Tetrahymena sp. 6 (Brandl) were found free-living in natural habitats, whereas Tetrahymena sp. 4 (SIN) is a parasite of the guppy Poecilia reticulata. Wilhelm Foissner (personal communication) suggested that Tetrahymena sp. 1 (Foissner) could be a new species because of its capacity to form a macrostome. A study by Brandl et al. (2005) reported a close relationship of Tetrahymena sp. 6 (Brandl) to $T$. mobilis and T. tropicalis based on SSU rDNA sequences. Similar relationships were found in our study, in which $T$. mobilis and some T. tropicalis isolates grouped with this isolate using both the coxl gene and SSU rDNA sequences. Although Tetrahymena sp. 4 (SIN) as well as Tetrahymena sp. 2 (CO), Tetrahymena sp. 3 (RA9) and Tetrahymena sp. 5 (NI) were found as parasites of the guppy Poecilia reticulata, Tetrahymena sp. 4 (SIN) was not closely related to the other three isolates, showing a considerable degree of genetic distance, $7.79 \%$ based on the coxl sequence. Thus, Tetrahymena sp. 1 (Foissner), Tetrahymena sp. 4 (SIN) and Tetrahymena sp. 6 (Brandl) likely represent new species of Tetrahymena on the basis of coxl gene sequences.

Interspecific sequence divergence among Tetrahymena sp. 2 (CO), Tetrahymena sp. 3 (RA9) and Tetrahymena sp. 5 (NI) ranged from 0.22 to $1.17 \%$ based on coxl gene sequences. Furthermore, these three new isolates showed a sequence divergence of $9.08 \%$ from other Tetrahymena species. Given that the range of intraspecific divergence among animals and Tetrahymena species is generally around $1-2 \%$, these three isolates, together with two $T$. tropicalis strains $\left(\right.$ ATCC $^{\circledR} 205083^{(i m}$ and ATCC $^{\circledR}$ $\left.205097^{(\mathbb{m}}\right)$, likely belong to the same new species, as indicated by less than $0.73 \%$ coxl sequence divergence among them. Additionally, this is supported by the ecological fact that the three new isolates are all apparently parasites of the guppy Poecilia reticulata, although a parasitic nature has not yet been demonstrated for $T$. tropicalis.

\section{CONCLUSIONS}

Our study illustrates the potential utility of coxl gene sequences in identifying the closely allied species of the ciliate genus Tetrahymena as well as other tetrahymenine species examined. This study extends the spectrum of applicability of universal DNA barcodes for biological identification to ciliophoran protists. In addition, the study showed that the nucleotide length of $689 \mathrm{bp}$ of the coxl gene is sufficient to provide a diagnostic signal for the identification of tetrahymenine ciliates. Furthermore, this 689 bp cox1 barcoding region gives a unique diagnostic sequence for each taxonomic species, with a few exceptions that may be explained by cultures being misidentified or contaminated. Two noteworthy exceptions, T. pyriformis and $T$. tropicalis, will require additional taxonomic reexamination, as they may represent new cryptic species complexes.

Our results indicated that the coxl-based identification system should be applied as a tool by culture collections and research laboratories to authenticate and verify their collections, since unintentional mix-ups or losses of cell lines can happen. On one hand, our study indicated that the coxl barcode will be a powerful alternative in the biological identification of ciliates, especially those whose SSU rDNAs, which have long been used as putative 
'barcodes', are identical or very similar. This will speed up the discovery of cryptic ciliate species and also provide new insights into ciliate biodiversity. On the other hand, several scientific communities, such as ecologists, population biologists, parasitologists and evolutionary biologists, whose work requires the identification of the organisms, will be able to use our coxl-based identification approach without needing taxonomic expertise on a particular group.

\section{ACKNOWLEDGEMENTS}

We are grateful to the ATCC for kindly providing cultures of Tetrahymena. In addition, our sincere gratitude is extended to all scientists who generously provided us with wild isolated cultures: Professor Dr Wilhelm Foissner, Dr Dina Zilberg and Miss Marcia P. Leibowitz. We wish to express our gratitude to Professor Clifford F. Brunk for kindly providing sequences of the coxl gene for Tetrahymena paravorax and other Tetrahymena species to facilitate our primer design and to Dr Michaela C. Strüder-Kypke for kindly providing sequences of the coxl gene for some Tetrahymena species for our analyses. This research was supported through funding to the Canadian Barcode of Life Network from Genome Canada through the Genomics Institute, a NSERC of Canada Discovery Grant awarded to D. H. L. and other sponsors (listed at http://www.BOLNET.ca). C. C. was supported by a national scholarship awarded by the Cooperative Research Network (CRN), Government of Thailand. Finally, we are thankful to three anonymous reviewers for their constructive and helpful comments on earlier drafts of the manuscript.

\section{REFERENCES}

Avise, J. C. (2000). Phylogeography: the History and Formation of Species. Cambridge, MA: Harvard University Press.

Ball, S. L., Hebert, P. D. N., Burian, S. K. \& Webb, J. M. (2005). Biological identifications of mayflies (Ephemeroptera) using DNA barcodes. J N Am Benthol Soc 24, 508-524.

Barrett, R. D. H. \& Hebert, P. D. N. (2005). Identifying spiders through DNA barcodes. Can J Zool 83, 481-491.

Barth, D., Krenek, S., Fokin, S. I. \& Berendonk, T. U. (2006). Intraspecific genetic variation in Paramecium revealed by mitochondrial cytochrome $c$ oxidase I sequences. J Eukaryot Microbiol 53, 20-25.

Borden, D., Whitt, G. S. \& Nanney, D. L. (1973a). Electrophoretic characterization of classical Tetrahymena pyriformis strains. J Protozool 20, 693-700.

Borden, D., Whitt, G. S. \& Nanney, D. L. (1973b). Isozymic heterogeneity in Tetrahymena strains. Science 181, 279-280.

Borden, D., Miller, E. T., Whitt, G. S. \& Nanney, D. L. (1977). Electrophoretic analysis of evolutionary relationships in Tetrahymena. Evolution 31, 91-102.

Brandl, M. T., Rosenthal, B. M., Haxo, A. F. \& Berk, S. G. (2005). Enhanced survival of Salmonella enterica in vesicles released by a soilborne Tetrahymena species. Appl Environ Microbiol 71, 1562-1569.

Brown, J. W., Miller, S. E. \& Horak, M. (2003). Studies on New Guinea moths. 2. Description of a new species of Xenothictis Meyrick (Lepidoptera: Tortricidae: Archipini). Proc Entomol Soc Wash 105, 1043-1050.

Brunk, C. F., Lee, C. L., Tran, A. B. \& Li, J. (2003). Complete sequence of the mitochondrial genome of Tetrahymena thermophila and comparative methods for identifying highly divergent genes. Nucleic Acids Res 31, 1673-1682.
Burger, G., Zhu, Y., Littlejohn, T. G., Greenwood, S. J., Schnare, M. N., Lang, B. F. \& Gray, M. W. (2000). Complete sequence of the mitochondrial genome of Tetrahymena pyriformis and comparison with Paramecium aurelia mitochondrial DNA. J Mol Biol 297, 365-380.

Corliss, J. O. (1952). Le cycle autogamique de Tetrahymena rostrata. $C$ $R$ Acad Sci 235, 399-402 (in French).

Corliss, J. O. (1953). Silver impregnation of ciliated protozoa by the Chatton-Lwoff technic. Stain Technol 28, 97-100.

Corliss, J. O. (1972). Tetrahymena and some thoughts on the evolutionary origin of endoparasitism. Trans Am Microsc Soc 91, 566-573.

Corliss, J. O. (1973). History, taxonomy, ecology, and evolution of species of Tetrahymena. In Biology of Tetrahymena, pp. 1-55. Edited by A. M. Elliott. Stroudsburg, PA: Dowden, Hutchinson \& Ross.

Corliss, J. O. \& Daggett, P.-M. (1983). "Paramecium aurelia" and "Tetrahymena pyriformis": current status of the taxonomy and nomenclature of these popularly known and widely used ciliates. Protistologica 19, 307-322.

Cummings, D. J. (1992). Mitochondrial genomes of the ciliates. Int Rev Cytol 141, 1-64.

Czapik, A. (1968). La famille Tetrahymenidae et son importance dans la systématique et l'évolution des ciliés. Acta Protozool 5, 315-357 (in French).

Dawkins, R. (1998). Unweaving the Rainbow: Science, Delusion and the Appetite for Wonder. Boston: Houghton Mifflin.

Elliott, A. M. (1970). The distribution of Tetrahymena pyriformis. J Protozool 17, 162-168.

Elwood, H. J., Olsen, G. J. \& Sogin, M. L. (1985). The small-subunit ribosomal RNA gene sequences from the hypotrichous ciliates Oxytricha nova and Stylonychia pustulata. Mol Biol Evol 2, 399-410.

Felsenstein, J. (2004). PHYLIP (phylogeny inference package), version 3.6. Distributed by the author. Department of Genome Sciences, University of Washington, Seattle, USA.

Fenchel, T. \& Finlay, B. J. (2004). The ubiquity of small species: patterns of local and global diversity. Bioscience 54, 777-784.

Folmer, O., Black, M., Hoeh, W., Lutz, R. \& Vrijenhoek, R. (1994). DNA primers for amplification of mitochondrial cytochrome $c$ oxidase subunit I from diverse metazoan invertebrates. Mol Mar Biol Biotechnol 3, 294-297.

Gruchy, D. F. (1955). The breeding system and distribution of Tetrahymena pyriformis. J Protozool 2, 178-185.

Hajibabaei, M., Janzen, D. H., Burns, J. M., Hallwachs, W. \& Hebert, P. D. N. (2006). DNA barcodes distinguish species of tropical Lepidoptera. Proc Natl Acad Sci U S A 103, 968-971.

Hebert, P. D. N., Ratnasingham, S. \& deWaard, J. R. (2003a). Barcoding animal life: cytochrome $c$ oxidase subunit 1 divergences among closely related species. Proc Biol Sci 270 (Suppl. 1), S96-S99.

Hebert, P. D. N., Cywinska, A., Ball, S. L. \& deWaard, J. R. (2003b). Biological identifications through DNA barcodes. Proc Biol Sci 270, 313-321.

Hebert, P. D. N., Penton, E. H., Burns, J. M., Janzen, D. H. \& Hallwachs, W. (2004a). Ten species in one: DNA barcoding reveals cryptic species in the neotropical skipper butterfly Astraptes fulgerator. Proc Natl Acad Sci U S A 101, 14812-14817.

Hebert, P. D. N., Stoeckle, M. Y., Zemlak, T. S. \& Francis, C. M. (2004b). Identification of birds through DNA barcodes. PLoS Biol 2, e312.

Hogg, I. D. \& Hebert, P. D. N. (2004). Biological identification of springtails (Hexapoda: Collembola) from the Canadian Arctic, using mitochondrial DNA barcodes. Can J Zool 82, 749-754. 
Holz, G. G. \& Corliss, J. O. (1956). Tetrahymena setifera n. sp., a member of the genus Tetrahymena with a caudal cilium. J Protozool 3, 112-118.

Janczewski, D. N., Modi, W. S., Stephens, J. C. \& O'Brien, S. J. (1995). Molecular evolution of mitochondrial 12S RNA and cytochrome $b$ sequences in the pantherine lineage of Felidae. Mol Biol Evol 12, 690-707.

Jerome, C. A. \& Lynn, D. H. (1996). Identifying and distinguishing sibling species in the Tetrahymena pyriformis complex (Ciliophora, Oligohymenophorea) using PCR/RFLP analysis of nuclear ribosomal DNA. J Eukaryot Microbiol 43, 492-497.

Kahl, A. (1926). Neue und wenig bekannte Formen der holotrichen und heterotrichen Ciliaten. Arch Protistenkd 55, 197-438 (in German).

Kimura, M. (1980). A simple method of estimating evolutionary rates of base substitutions through comparative studies of nucleotide sequences. J Mol Evol 16, 111-120.

Kumar, S., Tamura, K. \& Nei, M. (2004). MEGA3: integrated software for molecular evolutionary genetics analysis and sequence alignment. Brief Bioinform 5, 150-163.

Kumazawa, Y. \& Nishida, M. (1993). Sequence evolution of mitochondrial tRNA genes and deep-branch animal phylogenetics. J Mol Evol 37, 380-398.

Lynn, D. H. \& Strüder-Kypke, M. C. (2006). Species of Tetrahymena identical by small subunit rRNA gene sequences are discriminated by mitochondrial cytochrome $c$ oxidase I gene sequences. J Eukaryot Microbiol 53, 385-387.

Mardulyn, P. \& Whitfield, J. B. (1999). Phylogenetic signal in the COI, $16 \mathrm{~S}$, and $28 \mathrm{~S}$ genes for inferring relationships among genera of Microgastrinae (Hymenoptera; Braconidae): evidence of a high diversification rate in this group of parasitoids. Mol Phylogenet Evol 12, 282-294.

Medlin, L., Elwood, H. J., Stickel, S. \& Sogin, M. L. (1988). The characterization of enzymatically amplified eukaryotic 16S-like rRNA-coding regions. Gene 71, 491-499.

Meyer, E. B. \& Nanney, D. L. (1987). Isozymes in the ciliated protozoa. In Isozymes (Current Topics in Biological and Medical Research, vol. 13), pp. 61-101. Edited by M. C. Rattazzi. New York: Alan R. Liss.

Monaghan, M. T., Balke, M., Gregory, T. R. \& Vogler, A. P. (2005). DNA-based species delineation in tropical beetles using mitochondrial and nuclear markers. Philos Trans R Soc Lond B Biol Sci 360, 1925-1933.

Nanney, D. L. \& McCoy, J. W. (1976). Characterization of the species of the Tetrahymena pyriformis complex. Trans Am Microsc Soc 95, 664-682.

Nanney, D. L., Meyer, E. B., Simon, E. M. \& Preparata, R.-M. (1989). Comparison of ribosomal and isozymic phylogenies of tetrahymenine ciliates. J Protozool 36, 1-8.

Nanney, D. L., Park, C., Preparata, R. \& Simon, E. M. (1998), Comparison of sequence differences in a variable $23 \mathrm{~S}$ rRNA domain among sets of cryptic species of ciliated protozoa. J Eukaryot Microbiol 45, 91-100.

Nelsen, E. M. \& Debault, L. E. (1978). Transformation in Tetrahymena pyriformis: description of an inducible phenotype. J Protozool 25, $113-119$.

Nyberg, D. (1981). Three new "biological" species of Tetrahymena ( $T$. hegewischi n. sp., T. sonneborni n. sp., T. nipissingi n. sp.) and temperature tolerance of members of the "pyriformis" complex. J Protozool 28, 65-69.
Preparata, R. M., Meyer, E. B., Preparata, F. P., Simon, E. M., Vossbrinck, C. R. \& Nanney, D. L. (1989). Ciliate evolution: the ribosomal phylogenies of the tetrahymenine ciliates. J Mol Evol 28, 427-441.

Remigio, E. A. \& Hebert, P. D. N. (2003). Testing the utility of partial COI sequences for phylogenetic estimates of gastropod relationships. Mol Phylogenet Evol 29, 641-647.

Sadler, L. A. \& Brunk, C. F. (1992). Phylogenetic relationships and unusual diversity in histone $\mathrm{H} 4$ proteins within the Tetrahymena pyriformis complex. Mol Biol Evol 9, 70-84.

Saitou, N. \& Nei, M. (1987). The neighbor-joining method: a new method for reconstructing phylogenetic trees. Mol Biol Evol 4, 406-425.

Saunders, G. W. (2005). Applying DNA barcoding to red macroalgae: a preliminary appraisal holds promise for future applications. Philos Trans $R$ Soc Lond B Biol Sci 360, 1879-1888.

Scheffer, S. J., Lewis, M. L. \& Joshi, R. C. (2006). DNA barcoding applied to invasive leafminers (Diptera: Agromyzidae) in the Philippines. Ann Entomol Soc Am 99, 204-210.

Schlegel, M., Elwood, H. J. \& Sogin, M. L. (1991). Molecular evolution in hypotrichous ciliates: sequence of the small subunit RNA genes from Onychodromus quadricornutus and Oxytricha granulifera (Oxytrichidae, Hypotrichida, Ciliophora). J Mol Evol 32, 64-69.

Simon, E. M., Meyer, E. B. \& Preparata, R. M. (1985). New wild Tetrahymena from Southeast Asia, China, and North America, including Tetrahymena malaccensis, Tetrahymena asiatica, Tetrahymena nanneyi, Tetrahymena caudata, and Tetrahymena silvana n. spp. J Protozool 32, 183-189.

Smith, M. A., Fisher, B. L. \& Hebert, P. D. N. (2005). DNA barcoding for effective biodiversity assessment of a hyperdiverse arthropod group: the ants of Madagascar. Philos Trans R Soc Lond B Biol Sci 360, 1825-1834.

Sogin, M. L. \& Elwood, H. J. (1986). Primary structure of the Paramecium tetraurelia small-subunit rRNA coding region: phylogenetic relationships within the Ciliophora. J Mol Evol 23, 53-60.

Strüder-Kypke, M. C., Wright, A.-D. G., Jerome, C. A. \& Lynn, D. H. (2001). Parallel evolution of histophagy in ciliates of the genus Tetrahymena. BMC Evol Biol 1, 5.

Tautz, D., Arctander, P., Minelli, A., Thomas, R. H. \& Vogler, A. P. (2002). DNA points the way ahead in taxonomy. Nature 418, 479.

Tautz, D., Arctander, P., Minelli, A., Thomas, R. H. \& Vogler, A. P. (2003). A plea for DNA taxonomy. Trends Ecol Evol 18, 70-74.

Thompson, J. D., Higgins, D. G. \& Gibson, T. J. (1994). CLUSTAL W: improving the sensitivity of progressive multiple sequence alignment through sequence weighting, position-specific gap penalties and weight matrix choice. Nucleic Acids Res 22, 4673-4680.

Walsh, P. S., Metzger, D. A. \& Higuchi, R. (1991). Chelex 100 as a medium for simple extraction of DNA for PCR-based typing from forensic material. Biotechniques 10, 506-513.

Ward, R. D., Zemlak, T. S., Innes, B. H., Last, P. R. \& Hebert, P. D. N. (2005). DNA barcoding Australia's fish species. Philos Trans $R$ Soc Lond B Biol Sci 360, 1847-1857.

Williams, N. E., Buhse, H. E., Jr \& Smith, M. G. (1984). Protein similarities in the genus Tetrahymena and a description of Tetrahymena leucophrys n. sp. J Protozool 31, 313-321.

Ziaie, Z. \& Suyama, Y. (1987). The cytochrome oxidase subunit I gene of Tetrahymena: a 57 amino acid $\mathrm{NH}_{2}$-terminal extension and a 108 amino acid insert. Curr Genet 12, 357-368. 